\title{
WASF3 wt Allele
}

National Cancer Institute

\section{Source}

National Cancer Institute. WASF3 wt Allele. NCI Thesaurus. Code C138127.

Human WASF3 wild-type allele is located in the vicinity of $13 q 12.13$ and is approximately $131 \mathrm{~kb}$ in length. This allele, which encodes Wiskott-Aldrich syndrome protein family member 3 , is involved in cell morphology. 